\title{
Revisiting borders: Named languages and de-colonization
}

\author{
Mario Saraceni and Camille Jacob \\ University of Portsmouth
}

\begin{abstract}
Recent developments in sociolinguistics have been characterized by a move away from the notion of languages as discrete and separate entities. This has come within a frame of general criticism of structuralism as a theory of language fundamentally emanating from, or at least being tied to, monolingual ideologies of $19^{\text {th }}$-century European nationalism. Based on the recognition that linguistic borders are little more than political constructs, many sociolinguists prefer to describe language behavior as social practice where speakers make use of shared linguistic repertories in fluid and dynamic ways rather than adhering to the static rules of pre-packaged and labelled languages. Revealing the ideologically-driven monolingual bias in applied and sociolinguistics, this work focusses instead on translanguaging and/or translingual practices, and has been immensely important in putting forward a more adequate understanding of language.

However, this intellectual impetus should not lead us to lose sight of the fact that, invented and artificial as they may have been, named languages and their borders do exist and play very important roles not only as layman's concepts but also as part of the long process of political and cultural de-colonization in many parts of the world. The celebration of translanguaging as a better and more sophisticated analytical lens need not come with the denigration of other understandings. The argument against one bias must not simultaneously develop its own biases. While the notion of translanguaging helps us describe language behaviors in more adequate ways and can also usefully inform pedagogical practices, the political as well as practical consequences and potential benefits of nationally-defined languages must also be seriously considered within a sociolinguistics of globalization. This paper examines this point by considering the cases of the sociolinguistic situations in Malaysia and Algeria.
\end{abstract}

KEYWORDS: Named languages, de-colonization, nation-state, translanguaging, identities

\section{Introduction}

The beginning of the $21^{\text {st }}$ century has seen a mini revolution in sociolinguistics. Vertovec (2007)'s sociological study on what he called 'super-diversity' brought to the fore the fact that contemporary urban demographics in western cities had become so multi-faceted that it could no longer be described simply in terms of a multitude of single, neatly distinct traits (e.g. nationality, language, etc.). From this perspective, the acknowledgement and the description of a plurality of coexisting languages, ethnic groups and so on through the use of the prefix multi- in adjectives such as multilingual, multiethnic or multicultural did not capture the complex intersection of variables - including also legal status, labor market experiences, spatial distribution, access to services, etc. - which characterize the social make up of contemporary cities. Describing a city like London as 'multicultural', for example, is generally meant to account for the fact that the same urban space is shared by people from different cultures. But the limitation of such a description is that it assumes a neat identification and distinction of such 'cultures' (whatever one may mean by this term) and consequently, without taking into account any other social trait, classifies people into pre-defined boxed categories that never merge. A multicultural society is then simply one where a collection of 'cultures' coexist. The re-conceptualization of diversity into super-diversity aims to offer a much more refined description of urban societies, where cultures, languages, ethnicities are more fluid and are considered together with a number of other aspects of people's roles in society (see also Vertovec, 2010; Vertovec, 2016). The principal paradigmatic shift produced by the notion of 'super-diversity', therefore, is one 
whereby descriptions which follow border lines between fixed categories are not helpful in our understanding of complex phenomena.

Parallel to, and in part inspired by, this work, much academic activity developed in sociolinguistics examining what one might call 'linguistic border crossings'. Central to this scholarship has been the idea that, just like the demographic composition of large cities like London or New York, the constellation of languages in use in any given (especially urban) locality should not be understood simply as the co-existence of a number of distinct languages side by side, but as a complex and rich repertoire of semiotic resources that people share to different degrees and draw from according to their particular needs in any particular context of communication. From this perspective, just like the notion of 'diversity' is incapable of describing the demography of contemporary urban societies and thus needs the prefix super- to signify great levels of complexity, the term 'multilingualism' suffers from the same deficiency, as the prefix 'multi-' does little more than point to the existence or use of more than one language in the same community. So, the identification of this limitation has prompted a number of sociolinguists to apply the concept of super-diversity to our understanding and analysis of language (Blommaert and Rampton, 2011), where the focus of attention has centred very much on the fuzziness of linguistic borders, the hybrid nature of language practice (Rubdy and Alsagoff, 2013) and on the seamless and natural simultaneous use of more than one language in the same instances of communication (Canagarajah, 2013; García and Li, 2014; Li, 2017).

\subsection{Destabilizing nation-state ideology}

This ferment of academic activity has taken issue with, and advocated a move away from, two interrelated biases in linguistics: (a) the 'monolingual bias' (Pavlenko, 2007; Yildiz, 2012), namely the tendency to regard monolingualism as the norm against which all other linguistic competencies are judged, and (b) the structuralist view of language-as-code bias (Canagarajah, 2017), according to which language is a self-contained bounded system that can, and should, be studied in its own right. Both these biases derive from an objectification of language seen as a natural component of every individual's identity, acting together with other equally objectified characteristics, such as the person's 'culture', 'nationality', 'ethnicity', 'religion' - a notion deriving from $19^{\text {th }}$-century European nation-state ideology, according to which each nation is naturally and indissolubly bound to a territory, a connection cemented by that people's unique culture, ethnicity and, crucially, language (Silverstein, 2010). Significantly, the 'identificational function [of these features] implies separability, a natural discontinuity in the real world [and] [t]hese discontinuities are "nations" or "peoples"- that is, natural groups, the folk perception of which conceptualizes them in much the same way as species in the animal kingdom' (Blommaert and Verschueren, 1998: 262, see also Schneider this issue). From this perspective, all of these traits are well-identifiable and exclude any form of hybridity or fluidity and national boundaries and linguistic boundaries coincide, hence the naming of national languages such as Deutsch, italiano or français: in the same way as one can only naturally belong to one culture, one nationality, one ethnic group, one can only have one language. And any disruption of this one-ness of traits is regarded as special and somewhat unnatural. Thus, the rejection of this ideology stems from the realization that the nation state, as a political, social and economic entity, is being weakened by globalization. Indeed, it was already twenty years ago that Robinson (1998) recommended that 'a new multidisciplinary field of transnational studies should be predicated on a decisive break with the nation-state framework of analysis, and diverse transnational phenomena and processes should constitute its general subject matter' (589), and this is particularly relevant when it comes to examining the role of language in such trans- and post-national social phenomena (Wright, 2016).

\subsection{Translanguaging}

Of the many terms that have been coined in sociolinguistics in recent years to describe the fluid interplay of languages within people's linguistic repertoires (Pennycook, 2016), translanguaging seems to be the one that has caught on more decidedly. The term refers to 'using one's idiolect, that is one's linguistic repertoire, without regard for socially and politically defined language names and labels' ( $\mathrm{Li}, 2017: 11)$. The concept of translanguaging is also often used in open opposition to older terms such as code-switching, as this still very much implies the clear identification of two distinct codes (but see Pennycook, 2016: for a useful discussion on the meaning of code-switching), whereas translanguaging 
considers language use primarily as a social practice and irrespective of whichever names one might wish to attach to chunks of verbal communication. This means that the 'boundaries between languages, between languages and other communicative means, and the relationship between language and the nation-state are being constantly reassessed, broken, or adjusted by speakers on the ground' ( $\mathrm{Li}, 2017: 7)$. And, in turn, this also entails a destabilization and a redefinition of certain core concepts in linguistics, such as that of $a$ language as well as that of a speaker of any one language. If people communicate by drawing from a pool of available linguistic and semiotic resources that they (partly) share with other people, and use different languages simultaneously in amalgams where language labels don't matter, what do names such as 'English', 'French', 'Malay', 'Cantonese', 'Tamil' 'Arabic' and so on really refer to?

\subsection{Aims of this paper}

All this work has contributed to questioning some deep-rooted biases and has helped move our understanding of language forward. However, this academic fervour, driven by contagious enthusiasm, may have not fully considered some of the societal implications of the language practices championed in the 'translanguaging turn'. The frequency of linguistic border crossings does not necessarily make them societally as legitimate as linguistic behavior that is more respectful, as it were, of borders, artificial as these may be. For example, one important issue relates the power and prestige accorded to named, 'standard' languages (J. Milroy and L. Milroy, 2012) and the lack thereof in whatever might be considered hybrid forms. In this regard, Kubota (2015: 33) asks:

Do the apparent fluid and unhindered linguistic practices reflect individual freedom or are they enmeshed with ideology and unequal power relations? Who has resources and access to acquire hybrid English codes in the first place? What potential social consequences are imposed on hybrid language users and are such consequences unevenly experienced? Can all English users regardless of their racial, gender, socioeconomic, and other background equally transgress linguistic boundaries and engage in hybrid and fluid linguistic practices?

These are important questions, whose validity transcends the analytical advantages inherent in a translanguaging-oriented theory of language ( $\mathrm{Li}, 2017)$. Crucially, it also transcends the capacity for translanguaging to liberate language users and learners from the straitjacket of monolingual ideology. Transgression is often a privilege whose benefits are not equally distributed. Paradoxically, therefore, in challenging old ideas, a translanguaging perspective may produce its own bias, characterized by a degree of socio-political naivety. Thus, without falling in an 'either/or' trap, in this paper we would like to turn the medal to the other side and consider the roles that named languages play with particular reference to contexts of de-colonization, where people's linguistic repertoires often include former colonial languages. In doing this, our starting point is Spolsky (2004: 133)'s assertion that '[t]he proclamation of national monolingualism, on the principle of "one nation, one state, one language," in a language other than that of the previous colonial power was (and remains) an obvious method of asserting real independence'.

What makes this point particularly cogent is the fact that much of the scholarship on translanguaging does indeed operate within the frame of de-colonization, as we illustrate in the next section.

\section{Translanguaging and de-colonization}

While the most visible impetus to questioning the validity of the idea of named languages as discrete, neatly packaged, nationally-defined entities may have come from examining contemporary contexts marked by global cultural flows, mobility and urban super-diversity, an important aspect of the critique concerns the ways in which the very concept of named national languages is inextricably linked to European colonialism. When European empires controlled large parts of the world, especially during the $19^{\text {th }}$ and early $20^{\text {th }}$ centuries, the colonizing powers were engaged not only in defining nation states in Europe, but also in mapping, literally and metaphorically, the rest of the world. The 'scramble for Africa' (Chamberlain, 2010; Pakenham, 1991) undoubtedly represented the most obvious manifestation of this monumental enterprise. Britain, France, Belgium, Portugal, Germany and Italy infamously carved up almost the entire African continent among themselves. Domination of this scale was not only a matter of the forceful imposition of external control over seized land, its people and its resources, but it also involved a large-scale systematic re-definition 
of the world of the dominated according to the will, the parameters and, especially, the interests of those dominating powers. Names were invented to designate territories, peoples and even languages in ways that had little or nothing to do with the actual geography, ethnography or cultural and linguistic practices of the subjugated areas. The only concern for the Europeans was to invent names that would help map the territory in such a way as to reflect the divisions that they had established (Mignolo, 2000).

As an example, the country we now call Nigeria was an invention of the British. This extract from an article published in the London Times on 8 January 1897 explains the choice of the word 'Nigeria' to designate the territory over which the Royal Niger Company had managed to secure control:

In the first place, as the title "Royal Niger Company Territories" is not only inconvenient to use, but to some extent is also misleading, it may be permissible to coin a shorter title for the agglomeration of pagan and Mohammedan states which have brought, by the exertions of the Royal Niger Company, within the confines of a British Protectorate and thus need for the first time in their history to be described as an entity by some general name. [...]. The name "Nigeria" applying to no other portion of Africa may, without offence to any neighbours, be accepted as co-extensive with the territories over which the Royal Niger Company has extended British influence, and may serve to differentiate them equally from the British colonies of Lagos and the Niger Protectorate on the coast and from the French territories of the Upper Niger.

Nigeria, thus understood, covers, as is well known, a thickly-peopled area of about half-a-million square miles [...]. [It] contains many widely-differing characteristics of climate, country, and inhabitants. Its history is ancient and is not wanting in dramatic elements of interest and romance. (Shaw, 1897)

The passage makes it very clear that Nigeria was an invention of British colonialism. It was part of the way in which the British, the French and other European powers (Britain's 'neighbours') were organizing their respective control over African soil. And the act of naming was absolutely crucial to that process. The establishment of a name to designate a particular area was equivalent to decreeing its existence as a unified territorial entity. The Times article demonstrates the extraordinary power of a name: as soon as the name 'Nigeria' is coined, a shift takes place from something that was only a loose 'agglomeration of pagan and Mohammedan states' to, a few lines later, a well-defined territory with its own ancient, dramatic and romantic history. The fact that it contained 'many widely-differing characteristics of climate, country, and inhabitants' didn't make it any less unified or real - the existence of the name 'Nigeria' was, effectively, a proxy for the existence of a nation with its own territory.

The renaming exercise that was part of the remapping of the colonial world was not only geographical but also ethnographic and linguistic (Bolton and Hutton, 2000). In essence, this was done in order to complete the construction of socio-political entities that would look as much as possible like homogeneous nation-states, with all their obligatory components: identifiable and nameable territory, people, history and language. In particular, the role that the description and naming of languages played in the early stages of European colonization is explained very clearly by Irvine (2008):

The linguistic research that identified particular African languages, although conceived as recognizing distinct objects of study, often involved a practice of lumping together or splitting apart linguistic varieties in order to produce territorially regimentable language boundaries. Language, ethnicity, and territory were supposed to coincide, and to define population units on an administratively manageable scale - not too small, and not too large. Whatever shapes African societies had taken previously, and however variable or multifarious their populations' ways of speaking, the moment of colonization is when they were given that particular inflection that turns cultural traditions and genealogies into 'ethnicity,' turns linguistic practices into named 'languages' corresponding (supposedly) to ethnic groups, and interprets multilingualism as a secondary effect. (Irvine, 2008: 338)

And this is precisely what makes Makoni and Pennycook (2007: 21) say that it is the moral duty of sociolinguists to remedy to that 'epistemic violence' and 'to put languages back into the world.' So, from this point of view, the notion of translanguaging represents an antidote, a contrapuntal reading, and an alternative theory of language that breaks free from the monolingual straitjacket that has come as part and parcel of European colonization. It 'releases histories and understandings that had been buried within fixed language identities constrained by nation-states' (García and Li, 2014: 
21). García's work, in particular, is inspired by Walter Mignolo's concept of 'an other tongue', which, transcending colonial understandings of peoples, territories, nationalities, memories, religions, becomes 'the necessary condition for "an other thinking" and for the possibility of moving beyond the defense of national languages and national ideologies - both of which have been operating in complicity with imperial powers and imperial conflicts' (Mignolo, 2000: 249).

Indeed, much of the work on translanguaging insists on the point that the simultaneous use of languages and other semiotic resources is not a special or unusual phenomenon, but is 'the normal mode of communication that, with some exceptions in some monolingual enclaves, characterizes communities throughout the world' (García, 2009: 44). Even "[w]hat [...] [w]e term the "English" language has, in fact, existed under conditions we might well term "super-diversity" since the end of the $8^{\text {th }}$ century C.E.' (Silverstein, 2010: 9). Therefore, '[p]ostmodern social conditions and discourses didn't create translingual practices. They have only created more visibility for them' (Canagarajah, 2013: 37). From this perspective, monolingualism is primarily a product of Western ideologies that have promoted 'bounded notions of community and identity [...] [and] have also subtly distorted and even suppressed vibrant practice' (p. 34) not only in the West but also elsewhere, via colonization. Thus, 'the concept of language, and indeed the "metadiscursive regimes" used to describe languages are firmly located in Western linguistic and cultural suppositions. They do not describe any real state of affairs in the world' (Makoni and Pennycook, 2007: 27). In line with this analysis, and with specific reference to pre-colonial Africa, Makoni (2011: 681) points out how ' $[t]$ he idea of language as understood in western scholarship [...] is [...] a "myth" [...] part of a process of invention, a process set in motion in colonial Africa', prior to which 'the speech forms used for communication were simply referred to as isintu (human speak)".

At this point, without any need to reject the epistemological stance described above, the questions we wish to address are: (a) do named languages have any meaningful role in the process of de-colonization? (b) to what extent does 'an other thinking' actually play out in the ways discourses about, and practice in, language(s) engender identities (national or otherwise) in the complex processes of de-colonization? (c) does the 'translanguaging turn' risk producing its own bias in describing sociolinguistic phenomena? In the next section we begin to explore the role of named languages in the context of de-colonization.

\section{Named languages and de-colonization}

De-colonization involves much more than the political independence of territories (Chafer, 2017), and the biggest and most complex task for those in post-colonial settings is 'decolonizing the mind' (Ngũgĩ wa Thiong'o, 1986). Indeed, famously for Ngũgĩ wa Thiong'o the language question is absolutely central to this process. According to him, one's mind cannot be truly and fully de-colonized while the former colonial language continues to occupy a prominent position in their life, especially if this is to the detriment of local languages. In other words, just like the land needs to be rid of the invader, the mind needs to free itself from the invader's language. It is also important to remember that colonial languages such as English, French or Spanish enjoyed, and continue to do, positions of power and privilege in colonial settings, where the linguistic playing fields were, and still are, far from equal:

As is the case with economic markets [...] language markets are inherently unequal in that they ratify only particular languages / forms of language use as constituting primary cultural / symbolic capital. Since the global language market favours excolonial 'world' languages, and particularly English, they serve potentially to marginalize local / national languages by reducing their exchange, or purchasing value within formal domains. As was the case under colonialism, this shapes the language choices of people, in favor of economically powerful languages - and since language is intrinsic to culture - to some extent, also the lifestyles associated with them. (Rassool, 2007: 149)

Referring to a 2010 study involving Sri Lankan students, for example, Parakrama (2012: 121) noted how 'English still comes with strong colonial baggage and much extra-linguistic value added to it', given that

learners of English are actually hoping to become better human beings through English, and, as a corollary, people whose English is manifestly impeccable, in their eyes, are 'decent', 'punctual', team players, etc. 
Note, also, that the neo-colonial value system, which re-invests English in its colonial garb as the purview and prerogative of (white) English men and women, is also thriving here [...] The values espoused by these students are reminiscent of a by-gone era. (p. 122)

The situation described and decried by Parakrama is not peculiar to Sri Lanka and, in fact, it is very much what Franz Fanon referred to when he stated that ' $[t]$ he colonized is elevated above his jungle status in proportion to his adoption of the mother country's cultural standards' (Fanon, 1967: 18). It is against this backdrop that Spolsky (2004: 133, section 1)'s reference to local national monolingualism as an essential component of de-colonization must be understood. As an illustration of this, the case of post-colonial Malaysia is particularly telling.

\subsection{Named languages in post-colonial Malaysia}

Malaysia represents an ideal sociopolitical setting to illustrate the crucial importance of named languages in the context of de-colonization. Once it gained political independence in 1957, as a former British colony, Malaysia found itself in the situation of having to define its own, distinctive, national identity. As was the case in similar contexts, part of this process involved the crucial decision about what the national language was going to be. 'For the Malaysian government, building a contemporary postcolonial society meant defining the nation, by law, as culturally Malay' (Albury, 2017: 573). Within this context, the Malay language, Bahasa Melayu, was enshrined in the federal constitution (art. 152) as the national language, and became the sole official language in $1967^{1}$. Thus, the institution of a local language as the national language of independent Malaysia was an act that was expression of Spolsky's statement above and could be regarded as a bold move towards de-colonization. The choice was symbolically important not only for its contribution to building a national identity, but also because such an identity was ostensibly distinct from, and in opposition to, that of the colonial era.

However, this was by no means a straightforward process. It wasn't a simple matter a re-instating as official a language that had been relegated to a secondary status during the colonial period. As we discussed earlier, European imperialism didn't colonize existing nation states, with their own pre-existing national cultural and linguistic identities. It created and named territorial entities within whose makeshift borders lived people of different ethnic, cultural and linguistic backgrounds. Such demographic heterogeneity was a constant marker of colonization. So the question of the national language in newly independent countries was always a particularly thorny one since, inevitably, the selection of one group's language would automatically alienate and disadvantage everybody else who didn't belong to that group ${ }^{2}$. This was precisely the case in Malaysia. During their control of the Malay peninsula, the British adopted a 'divide et impera' strategy, whereby the main ethnic groups, Malays, Chinese and Indians, were kept apart from one another, 'with unequal economic status, and each maintaining separate cultures' (Noor and Leong, 2013: 716). This legacy is very much felt today. Indeed, Malaysians often describe the population of their country as being comprised of three 'races' ${ }^{3}$. While this is often stated as part of the celebration of the country's cultural richness and diversity, Malaysian society still bears the mark of the ethnic segregation that was in place during colonial times. One of the historical consequences of this separation in post-independence Malaysia was that the new nation was (and still is) largely defined along ethnic-cultural lines. In particular, the group that was numerically greater, the Malays, succeeded in establishing the principle that they were bumiputra ('children of the soil'), indicating a primordial connection to the land, and it was this special status that then formed the basis for the selection of Malay as the national language (Shamsul, 2001).

But the non-Malay part of the population had little or no attachment to the Malay language, as they used other languages in their communities: one of Hokkien, Cantonese, Mandarin, Hakka and others for Chinese Malaysians, and mostly Tamil for Indian Malaysians. Consequently, they saw Malay more as an imposition than as a vehicle of national liberation (Lee, 2007) ${ }^{4}$. For this reason, the name Bahasa Melayu ('Malay language') was later changed to

\footnotetext{
${ }^{1}$ A period of ten years was established during which English continued to play official roles.

${ }^{2}$ It was for this reason that in many cases post-independence language policies often resorted to keeping the former colonial language as (co-)official, as it was at least culturally equidistant to most people, regardless of their ethnic-cultural-linguistic backgrounds, and therefore less of a controversial choice (Rassool, 2007).

${ }^{3}$ The word 'race' is routinely used by Malaysians to refer to ethnic-cultural groups in the country.

${ }^{4}$ During the last few decades this situation has been very closely connected to the broader and more fundamental issue of the status of non-Malays
} 
Bahasa Malaysia, to explicitly signify that it was the language of the whole country and not just of one section of the population (Asmah Haji Omar, 1992). This name also had the added advantage of distinguishing the language from Bahasa Indonesia, a variant of Melayu which had been instituted as the national language of Malaysia's larger neighbor (for a discussion on the post-independence linguistic situation in Indonesia, see Reid, 2001). Indeed, Malaysian governments have been acutely aware of the risk that ethnic, religious and linguistic demarcation lines have posed to national unity. The concepts of Bangsa Malaysia ('Malaysian nation') in the 1980s and 1990s and, later, of 1Malaysia, have been based on the principle of unity in diversity, with the aim of promoting a sense of national identity equally shared by all Malaysians, but have not completely resolved the conundrum of reconciling this ambition with the higher status granted to the Malays, and the Malay language, over the other communities and their languages (Zhou and Wang, 2017). Thus, the notion of Bahasa Malaysia as the national language for all Malaysians has never been fully embraced, while identity affiliations have remained strong in relation to other languages (Coluzzi, 2017).

Mandarin and Tamil, in particular, are the two languages that play important roles for the non-Malay population. As is the case for the Malay language, the significance of these languages goes well beyond their communicative function. They are languages that most Chinese Malaysians (for Mandarin) and Indian Malaysian (for Tamil) consider their mother tongues, even though, significantly, this does not necessarily correspond to their ability to speak them (Albury, 2017). Mandarin is a heritage language that serves as a cultural identity marker for Chinese Malaysians, whose linguistic repertoire is varied and may include so-called 'dialects' such as Hokkien, Hakka, Cantonese, Teochew, as well as English, Malay and Mandarin itself, in different proportions. Tamil plays a similar function for the Indian community, whose repertoire also includes elements of Punjabi, Telugu, Malayalam besides, again, Malay and English.

Mandarin and Tamil, therefore, have great symbolic values in marking the distinctiveness of the Chinese and Indian communities from the Malay community. Interestingly, these linguistic border lines act in conjunction with religious ones. While Islam is one of the main defining features of Malay-ness, the Chinese community is largely Buddhist and the Indian community largely Hindu, with Christianity acting occasionally an alternative marker of non-Malay-ness for both communities. The point here is that the importance of these named languages is to be understood independently from actual language practices observable 'on the ground'. The latter is indeed often characterized by fluid linguistic border-crossings, whereby people simultaneously use elements of Malay, English, Hokkien, Tamil and so on, in what Malaysian call bahasa rojak (roughly, 'language salad'). But not only do these forms of translanguaging not tell the full story about language use in Malaysian society, but they also do not eliminate the role that named languages play in terms of social identity. Malaysians may occasionally display little respect for linguistic borders when they talk to one another, but they attach great symbolic value to languages as discrete entities.

This situation is by no means exclusive to Malaysia or to former British colonies. The case of Algeria, detailed in the rest of this paper, illustrates this particularly cogently.

\section{Named languages in Algeria}

\subsection{Language(s) of independence}

The Algerian territory was an Ottoman province until the early $19^{\text {th }}$ century, with the French conquest starting in 1830 and the northernmost regions integrated as three French départements in 1848. While the Sahara remained under military rule until 1957, northern Algeria was annexed as a supposedly 'full' part of France, and its status also stood in contrast to the later colonization of territories which would become French West Africa, or the protectorates established over Morocco and Tunisia. French became the official and administrative language, as well as the language of instruction, with traditional centres of learning closed, their lands confiscated, or required to apply for a near-impossible to obtain and highly restrictive teaching licence (Colonna, 1975: 29-34). Although 'Arabic' was officially part of the French schools' curriculum since 1892, teaching was delivered by French teachers and restricted to lessons in 'reading and writing the vernacular tongue', and in practice disappeared rapidly (Kadri, 2014). French schooling was viewed with suspicion, amplified by the absence of Arabic and Islamic teaching (seen as closely intertwined), and in the $19^{\text {th }}$ century

- and hence non-bumiputra - in the country, as they don't enjoy the same citizenship rights as the Malays, as a consequence of explicit legislation of affirmative action in favor of the latter that has been in place since the early 1970s (Pietsch and Clark, 2014). 
often equated with apostasy and forgetting one's culture (Colonna, 1975: 28; Turin, 1971). Early networks of school reformers and religious scholars in the $19^{\text {th }}$ century emphasized the importance of the Arabic language as a vector of cultural resistance and means to 'save the soul of the country' (Colonna, 1975: 34).

While education policies made linguistic questions more salient, citizenship rules operated along religious lines. The Jewish population of Algeria obtained French nationality in 1870 through the Crémieux Decree, and the European settlers' children acquired it automatically from 1889 onwards, irrespective of where their parents were from and how long they had been in Algeria (Blévis, 2001). By contrast, Muslims ${ }^{5}$ were considered French 'subjects' and as such could be conscripted into the French army, but had to first renounce their 'personal status' (the right to have matters pertaining to family law and inheritance judged by Muslim courts) before they could enjoy their full citizenship rights (Aissaoui, 2003, p. 194). Naturalization was equated with negating one's religion and traditions (McDougall, 2017: 151), and religious and ethnic categories were often conflated by the colonial authorities (Saada, 2012: 108), reinforcing the links between religious, linguistic, social and political identities. While not the only locus of colonial cultural conflict (McDougall, 2017: 100-118), personal status came to represent both 'the site in which the colonial oppression of Algerian Muslims was organized and exercised' as well as a symbol of a distinct Algerian culture (McDougall, 2006: 91).

Claims of a distinct Algerian identity would crystallize in the 1920s and 1930s into a number of movements which would later become (or be defined as) nationalist. For many of those movements, 'a unifying element was found in the religion and language that denied Algerians a place in French Algeria, namely Islam and Arabic' (Mouhleb, 2005: 83). Sheikh Adbelhamid Ben Badis founded the Association of Algerian Ulema (Muslim scholars) in 1931 and is considered one of the nationalist heroes of independent Algeria. He expressed the need to rekindle Algeria's Muslim and Arab roots (Evans, 2013: 52), through the creation of schools to teach Arabic, as well as social and cultural organizations such as sports clubs, theatres, scouts groups and newspapers (Evans, 2013: 52-54). The Association was first focused on religious reforms and becoming the exclusive authority on spiritual, moral and cultural matters (McDougall, 2006: 14), but also promoted the production of detailed histories emphasizing Algeria as a distinct nation. One of the most famous of these works, Al-Madani's Kitab Al-Jaza'ir (The Book of Algeria) included on its frontispiece the inscription 'Islam is our religion, Algeria is our homeland, Arabic is our language' which became one of the rallying cries of nationalists and an unofficial motto of independent Algeria. The first party to articulate their political demands as independence, Messali Hadj's Etoile NordAfricaine, also emphasized a national identity grounded in Islam and 'Arabness'. Both the ethnic and religious markers were strongly linked to the Arabic language, and demands around linguistic identity and policies featured in all parties' manifestos (Benrabah, 2013: 42-46).

While Algeria had always been a crossroads for intellectual life in the Middle East and in North and West Africa (Bennoune, 2002: 20; Scheele, 2010: 294), with Arabic and Islam playing a key role, understandings of these connections as between separate nations reflected re-constructions of the past with European conceptions of 'nation-states' as the main unit of political organization. Both Arabness and Islam-ness were foregrounded in response to colonial discursive constructions of the 'indigènes' as Muslims and Arabs, but also as an attempt to focus on a shared heritage which would supersede colonial divide-and-rule policies that have sought to pit Kabyles (Berbers from Kabylia, a region near Algiers) against Arabs (Aissaoui, 2003: 188; A. Taleb Ibrahimi, 2008: 36; Temlali, 2015). A certain representation of language (distinct, unitary, and linked to identity) therefore became key as both a political demand and a unifying trait for descriptions of an 'Algerian personality' (the most common term used during the $20^{\text {th }}$ century to denote an Algerian collective identity).

At independence, the priority remained building a new, separate nation-state through Arabization and Algerianization. 'Arabization' was recognized as a key policy of the newly independent state in the 1962 Tripoli program and the 1964 Algiers Charter, and Arabic was defined as 'the very expression of our country's values' (quoted in A. Taleb Ibrahimi, 2008: 44). As Benrabah argues, 'the core of Algerian nationalism was Arabic: the language question

\footnotetext{
5'Algériens' was claimed by European settlers to celebrate their identity as separate from the French from mainland France, and the term 'pieds-noirs' (Shepard, 2006) only originated after 1962 and would be anachronistic as descriptive of the colonial period. Today's 'Algerians' were first called 'indigènes', then 'Arabs' or 'Muslims', often interchangeably, with 'Muslim Christians' used to label the small minority who had converted to Christianity. The Jewish population switched categories from 'indigènes israélites' to 'French' in 1870 (Evans, 2012; Graebner, 2006; Prochaska, 1988). As mentioned earlier, naming and categorization was a cornerstone of colonial control, with ethnic and religious labelling used asymmetrically to create and maintain an 'Other' (Blévis, 2001: 575-578), and the reproduction of these categories in academic discussions is inherently problematic.
} 
stood high on the agenda of the national movement and drew its strength from its status as a bond between Islam and nationalism' (2013: 58). (Re)positioning Arabic as the language of politics, administration and education thus became 'a matter of cultural decolonization and social equity' (Berger, 2002: 2). Schools were the first major site where this focus on reclaiming the Algerian 'personality' was put in place, through reforms of the curriculum, teacher training and recruitment, the structure of the system itself and most importantly the language of instruction. Teaching and learning in the 'national language' was explained as a way of 'finding again [...] our original culture' (A. Taleb Ibrahimi, 2008: 42), 'the only possibility of countering the effects of cultural colonization' (K. Taleb Ibrahimi, 1995: 47). Most importantly, language and education policies allowed for discourses of a unitary cultural community, distinct from its colonial past and legitimate as a nation (Benmayouf, 2009: 117; McAllister, 2017: 50; Roberts, 2003), with Arabization becoming a shorthand for 'the defence of national values' (Cheriet, 1983: 9).

In addition to the different labels applied to Arabic, other named languages also retain their importance as proxies to discuss wider issues. As Rubdy describes in the case of India, paraphrasing Bourdieu (1991), 'languages are not [just] used for their communicative value, but are purely emblematic, used for their symbolic value' (2013: 57). Similarly, languages in Algeria are described as discrete, separate entities imbued with heavy symbolism. Standard Arabic becomes equated both to an 'authentic' Arabo-Muslim identity and an archaic idiom, Berber languages both to the origins (a 'true' Algerian identity) and to separatism, and French associated in turns with colonization and modernity (Atmane, 2013; Benbachir, 2012; Benrabah, 2007; Benstead and Reif, 2013; Berger, 1998; Euromonitor International, 2012; Mostari, 2004; Temim, 2007). Some authors go as far as to claim 'tell me what language you speak and I will tell you who you are' (Benmayouf, 2009: 15), with each speech act becoming a performance of a certain identity depending on the language it has been uttered in (Berger, 2002: 9). In terms of both state discourse and dominant language ideologies, the label itself often remains just as important as the content supposedly encapsulated by that named language.

\subsection{Naming, representations and practices}

The historical and contemporary emphasis on symbolic uses of named languages in postcolonial Algeria should not obscure the fact that it did not translate into standardized practices. In terms of Arabic, research into language use on radio and TV programs, advertising, official conferences, and even religious sermons and political speeches demonstrates how the boundaries between the formal and informal spheres are much more blurred than standard diglossia theory would suggest (Chachou, 2013; Sebaa, 1996; K. Taleb Ibrahimi, 1995). Even when looking at categories such as 'arabophone', 'francophone' and 'berberophone', which are often used as shorthand to discuss supposed factions within Algerian society (K. Taleb Ibrahimi, 1995; Benkhaled and Vince, 2017), with most people being multilinguals those labels are not as neatly defined and in fact can lead to 'performative paradoxes' (Berger, 2002: 3). The authors and composers of the national anthem were Berbers who had been schooled in both French and Arabic (Benrabah, 2013: 130), the Academy of Arabic Language was promoted, implemented and supervised by a Kabyle (Berber) and Arabization was being advocated for in French (Berger, 2002: 3-4, 28), with one of its main architects, A. Taleb Ibrahimi, preferring to hire 'bilinguals' for his ministry (A. Taleb Ibrahimi, 2008). Contemporary Arabic-language writers also speak French and 'usually adopt multiple identities with multilingualism as the vector of their literary works' (Benrabah, 2013: 154).

Even if people are acutely aware of the representations that named languages carry, daily practices rarely follow these neat delineations. From advertising to song lyrics and children's names, hybridity is the norm (Asselah-Rahal and Méfidène, 2007; Benmayouf, 2008: 72-74; Benrabah, 2015; Chachou, 2013; Cherrad, 2016: 84-87; Davies and Bentahila, 2006). To a certain extent, Maghrebi or Algerian Arabic itself can be understood as a manifestation of translanguaging, as the absence of standardization has allowed peopled to make use of the full extent of their linguistic repertoire, beyond distinctions of Arabic, Berber, French and English. Especially when considering the fluid use of language online, with its own evolving script(s) (using both Latin and Arabic scripts as well as numbers to symbolize sounds and letters absent from the Latin alphabet), 'one does not know whether they should be considered loanwords from another language [...] or simply part of a new language that is emerging globally, with no specific language affiliation' (Daoudi, 2011: 162).

Nonetheless, the discrepancies between named varieties and relatively unbounded language use does not translate into the irrelevance of those labels. Maghrebi Arabic, despite being widely used in most situations, remains the subject of negative representations because of a wider institutional discourse associating it with a 'bastardized dialect' (Chachou, 
2013: 54). The term derja (or darija), which is used by Algerians to describe the language they speak every day ${ }^{6}$, can be translated as 'spoken' but is often rendered by people as 'argot' or 'slang'. As Suleiman (2013) argues, 'socially available conceptualizations of the language' (p. 266), including the labels users attach to practices, should also be taken into account in understanding the validity of conceptual frameworks.

While some academics celebrate the creativity and dynamism of Algerian translanguaging, this is not how people understand their own practices. Younger people are often accused by older generations of being 'bilingual illiterates' who, because of the translanguaging nature of their communication, cannot master the separate standardized codes that are French and Arabic (Benrabah, 2007: 226-228; Dahou, 2016; Houache, 2015). Named languages remain one of the mechanisms of elite closure, with the symbolic value of so-called 'mastery' of these standards translating into greater access to jobs as well as differentiated cultural capital (Benazzouz, 2014; Cheriguen, 2007). Translanguaging might be one of the realities of daily linguistic practices in Algeria, but the discursive structuring power of named languages remain crucial not only in how the nation-state constructs itself, but also in how people define their identities (albeit in a complex and always shifting way).

\section{Conclusion}

The notion of translanguaging has gone a long way in bringing to the fore the constructedness of linguistic borders and the inherently hybrid nature of language practices. This, in turn, has helped attain a better and more sophisticated understanding of language as a social practice. However, we feel that these efforts may contain an inherent danger of throwing away the baby with the bathwater. In this paper, we have sought to highlight how, while translanguaging may be a useful concept to describe what goes on 'on the ground' when people actually talk to one another, the discursive structuring power of named languages remains crucial not only in how the nation-state constructed and continues to construct itself, but also in how people define and continue to re-negotiate their identities in the long and complex process of de-colonization.

\section{References}

Aissaoui, R. (2003). “Nous Voulons Dechirer Le Baillon Et Briser Nos Chaines': Racism, Colonialism and Universalism in the Discourse of Algerian Nationalists in France between the Wars'. In: French History 17(2), 186-209. DOI: 10.1093/fh/17.2.186.

Albury, N. J. (2017). 'Mother tongues and languaging in Malaysia. Critical linguistics under critical examination'. In: Language in Society 46(4), 567-589.

Asmah Haji Omar (1992). The linguistic scenery in Malaysia. Kuala Lumpur.

Asselah-Rahal, S. and T. Méfidène (2007). 'Enquêtes à Alger'. In: Plurilinguisme et enseignement des langues en Algérie. Rôles du français en contexte didactique. Ed. by S. Asselah-Rahal and P. Blanchet. Proximités. Fernelmont: EME Editions.

Atmane, Y. A. (2013). 'Analyse des catégorisations des langues auprès d'apprenants universitaires de Sidi-Bel-Abbès'. In: Synergies Algérie 20, 51-66.

Benazzouz, A. (2014). 'Le français, langue (refuge) pour la stigmatisation urbaine. ou quand les mots disent les maux'. In: Diasporisations sociolinguistiques et précarités. Discrimination(s) et mobilité(s). Ed. by T. Bulot, I. Boyer and M.-M. Bertucci. Paris: L'Harmattan, pp. 61-73.

Benbachir, N. (2012). 'Représentations des langues auprès des cadres de la Sonatrach'. In: Synergies Algérie 16, $147-153$.

Benkhaled, W. and N. Vince (2017). 'Performing Algerianness. The National and Transnational Construction of Algeria's “culture wars"”. In: Algeria. Nation, Culture and Transnationalism: 1988-2015. Ed. by P. Crowley. Liverpool: Liverpool University Press, pp. 243-269.

\footnotetext{
${ }^{6}$ In contrast to the Machreq, where colloquial Arabic is called 'amiyya.
} 
Benmayouf, C. Y. (2008). Renouvellement social, renouvellement langagier dans l'Algérie d'aujourd'hui. Paris: Editions L'Harmattan.

- (2009). La question linguistique en Algérie : Enjeux et perspectives. Biarritz: Séguier Editions.

Bennoune, M. (2002). The Making of Contemporary Algeria, 1830-1987. Cambridge: Cambridge University Press.

Benrabah, M. (2007). 'Language maintenance and spread: French in Algeria'. In: International Journal of Francophone Studies 10(1-2), 193-215.

- (2013). Language Conflict in Algeria: From Colonialism to Post-Independence. Bristol: Multilingual Matters.

- (2015). 'Défis pour la langue arabe à l'ère de la mondialisation et du 'Printemps démocratique'. In: Le social par le langage. La parole au quotidien. Ed. by M. Achour-Kallel. Tunis \& Paris: IRMC \& Karthala, pp. 185-202.

Benstead, L. J. and M. Reif (2013). 'Polarization or Pluralism? Language, Identity, and Attitudes toward American Culture among Algeria's Youth'. In: Middle East Journal of Culture and Communication 6(1), 75-106. Dor: 10.1163/18739865-00503005.

Berger, A.-E. (1998). 'Algeria in Other(s)' Languages: Toward a rethinking of Algeria's linguistic predicament'. In: Parallax 4(2), 43-46. DOI: 10.1080/135346498250235.

- ed. (2002). Algeria in Others' Languages. 1 edition. Ithaca: Cornell University Press.

Blévis, L. (2001). 'Les avatars de la citoyenneté en Algérie coloniale ou les paradoxes d'une catégorisation'. In: Droit et société 48(2). OCLC: 429478057, 557-581.

Blommaert, J. and B. Rampton (2011). 'Language and Superdiversity'. In: Diversities 13(2), 1-21.

Blommaert, J. and J. Verschueren (1998). 'The Role of Language in European Nationalist Ideologies'. In: Language Ideologies. Practice and Theory. Ed. by B. B. Schieffelin, K. A. Woolard and P. V. Kroskrity. Oxford: Oxford University Press, pp. 258-285.

Bolton, K. and C. Hutton (2000). 'Introduction. Orientalism, Linguistics and Postcolonial Studies'. In: Interventions. International Journal of Postcolonial Studies 2(1), 1-5.

Bourdieu, P. (1991). Language as Symbolic Power. Cambridge, Mass.: Harvard University Press.

Canagarajah, S. (2013). Translingual Practice: Global Englishes and Cosmopolitan Relations. London: Routledge.

- (2017). 'Translingual Practice as Spatial Repertoires. Expanding the Paradigm beyond Structuralist Orientations'. In: Applied Linguistics 39(1), 31-54.

Chachou, I. (2013). La situation sociolinguistique de l'Algérie: pratiques plurilingues et variétés à l'oeuvre. Paris: L'Harmattan.

Chafer, T. (26th Oct. 2017). 'Decolonization in French West Africa'. In: Oxford Research Encyclopedia of African History. URL: http:

//africanhistory.oxfordre.com/view/10.1093/acrefore/9780190277734.001.0001/acrefore9780190277734-e-166 (visited on 28/11/2017).

Chamberlain, M. E. (2010). The scramble for Africa. 3rd Edition. Harlow: Longman.

Cheriet, A. (1983). Opinion sur la politique de l'enseignement et de l'arabisation. Alger: Société nationale d'édition et de diffusion.

Cheriguen, F., ed. (2007). Les enjeux de la nomination des langues dans l'Algérie contemporaine. Paris: L'Harmattan.

Cherrad, N. (2016). 'Plurilinguisme et enseignement/apprentissage en cours de licence de français à l'université'. In: Pour un plurilinguisme algérien intégré: Approches critiques et renouvellement épistémique. Ed. by I. Chachou and M. Stambouli. Paris: Riveneuve Editions, pp. 67-89.

Colonna, F. (1975). Instituteurs algériens: 1883-1939. Paris: Presses de la Fondation nationale des sciences politiques.

Coluzzi, P. (2017). 'Language planning for Malay in Malaysia. A case of failure or success?' In: International Journal of the Sociology of Language 2017(244), 17-38.

Dahou, F. (2016). 'Modern Standard Arabic in Algeria'. In: International Journal of Language Studies 10(1), 31-48.

Daoudi, A. (2011). 'Globalization, Computer-mediated Communications and the Rise of e-Arabic'. In: Middle East Journal of Culture and Communication 4(2), 146-163.

Davies, E. E. and A. Bentahila (2006). 'Code switching and the globalisation of popular music: The case of North African rai and rap'. In: Multilingua - Journal of Cross-Cultural and Interlanguage Communication 25(4), 367-392. DOI: 10.1515/MULTI. 2006.020. 
Euromonitor International (2012). The Benefits of the English Language for Individuals and Societies. Quantitative Indicators from Algeria, Egypt, Iraq, Jordan, Lebanon, Morocco, Tunisia and Yemen. London: Euromonitor International.

Evans, M. (July 2012). ‘Algeria’s Jewish Question’. In: History Today (July 2012), 10-16.

- (2013). Algeria: France's Undeclared War. Oxford: Oxford University Press.

Fanon, F. (1967). Black Skin, White Masks. Trans. by C. L. Markmann. New York: Grove Press.

García, O. (2009). Bilingual Education in the 21st Century: A Global Perspective. Oxford: Wiley/Blackwell.

García, O. and W. Li (2014). Translanguaging: Language, Bilingualism and Education. Basingstoke: Palgrave Macmillan.

Graebner, S. (2006). '”Unknown and Unloved”: The Politics of French Ignorance in Algeria, 1860-1930'. In: Algeria \& France, 1800-2000; identity, memory, nostalgia. Ed. by P. Lorcin. Syracuse, N.Y.: Syracuse University Press, pp. 49-62.

Houache, O. (2015). Citoyen, quelle langue parles-tu? Je parle Algérien! Essai. Alger: Sedia.

Irvine, J. T. (2008). 'Subjected words. African linguistics and the colonial encounter'. In: Language \& Communication 28(4), 323-343.

Kadri, A. (2014). Instituteurs et enseignants en Algérie 1945-1975. Histoire et mémoires. Paris: Karthala.

Kubota, R. (2015). 'Inequalities of Englishes, English Speakers, and Languages. A Critical Perspective on Pluralist Approaches to English'. In: Unequal Englishes. The Politics of Englishes Today. Ed. by R. Tupas. Basingstoke: Palgrave, pp. 21-42.

Lee, H. G. (2007). 'Ethnic Politics, National Development and Language Policy in Malaysia'. In: Language, Nation and Development in Southeast Asia. Ed. by H. G. Lee and L. Suryadinata. Singapore: Institute of Southeast Asian Studies, pp. 118-149.

Li, W. (2017). 'Translanguaging as a Practical Theory of Language'. In: Applied Linguistics 39(1), 9-30.

Makoni, S. B. (2011). 'Sociolinguistics, colonial and postcolonial: an integrationist perspective'. In: Language Sciences 33(4), 680-688.

Makoni, S. B. and A. Pennycook (2007). 'Disinventing and Reconstituting Languages'. In: Disinventing and Reconstituting Languages. Ed. by S. B. Makoni and A. Pennycook. Clevedon: Multilingual Matters, pp. 1-41.

McAllister, E. (2017). 'Algeria's 'Belle Époque': Memories of the 1970s as a Window on the present'. In: Algeria: Nation, Culture and Transnationalism 1988-2015. Ed. by P. Crowley. Francophone Postcolonial Studies 8. Liverpool: Liverpool University Press, pp. 46-62.

McDougall, J. (2006). History and the Culture of Nationalism in Algeria. Cambridge: Cambridge University Press. - (2017). A History of Algeria. Cambridge: Cambridge University Press.

Mignolo, W. D. (2000). Local Histories/Global Designs. Coloniality, Subaltern Knowledges, and Border Thinking. Princeton: Princeton University Press.

Milroy, J. and L. Milroy (2012). Authority in Language: Investigating standard English. 4th Edition. London: Routledge.

Mostari, H. A. (2004). 'A sociolinguistic perspective on Arabisation and language use in Algeria'. In: Language Problems \& Language Planning 28(1), 25-44.

Mouhleb, N. (2005). 'Language and Conflict. Kabylia and the Algerian State'. MA Thesis. University of Oslo.

Ngũgĩ wa Thiong'o (1986). Decolonising the Mind: The politics of language in African literature. Portsmouth, NH: Heinemann.

Noor, N. M. and C.-H. Leong (2013). 'Multiculturalism in Malaysia and Singapore. Contesting models'. In: International Journal of Intercultural Relations 37(6), 714-726.

Pakenham, T. (1991). The Scramble for Africa: 1876-1912. London: Weidenfeld \& Nicolson.

Parakrama, A. (2012). 'The Malchemy of English in Sri Lanka: Reinforcing Inequality through Imposing Extra-Linguistic Value'. In: English Language as Hydra: Its Impacts on Non-English Language Cultures. Ed. by V. Rapatahana and P. Bunce. Bristol: Multilingual Matters, pp. 107-132.

Pavlenko, A. (2007). Emotions and Multilingualism. Cambridge: Cambridge University Press.

Pennycook, A. (2016). 'Mobile times, mobile terms. The trans-super-poly-metro movement'. In: Sociolinguistics. Theoretical Debates. Ed. by N. Coupland. Cambridge: Cambridge University Press, pp. 201-216. 
Pietsch, J. and M. Clark (2014). 'Citizenship rights in Malaysia. the experience of social and institutional discrimination among ethnic minorities'. In: Citizenship Studies 18(3-4), 303-314.

Prochaska, D. (1988). 'The political culture of settler colonialism in Algeria : politics in Bone (1870-1920)'. In: Revue de l'Occident musulman et de la Méditerranée 48(1), 293-311. DOI: 10.3406/remmm.1988.2245.

Rassool, N. (2007). Global Issues in Language, Education and Development. Perspectives from Postcolonial Countries. Clevedon: Multilingual Matters.

Reid, A. (2001). 'Understanding Melayu (Malay) as a Source of Diverse Modern Identities'. In: Journal of Southeast Asian Studies 32(3), 295-313.

Roberts, H. (Feb. 2003). The Battlefield: Algeria 1988-2002, Studies in a Broken Polity. 1 edition. London ; New York: Verso.

Robinson, W. I. (1998). 'Beyond Nation-State Paradigms: Globalization, Sociology, and the Challenge of Transnational Studies'. In: Sociological Forum 13(4), 561-594.

Rubdy, R. (2013). 'Hybridity in the Linguistic Landscape: Democratizing English in India'. In: The Global-Local Interface and Hybridity. Exploring Language and Identity. Ed. by R. Rubdy and L. Alsagoff. Bristol: Multilingual Matters, pp. 43-65.

Rubdy, R. and L. Alsagoff, eds. (2013). The Global-Local Interface and Hybridity. Exploring Language and Identity. Bristol: Multilingual Matters.

Saada, E. (2012). Empire's Children. Race, Filiation, And Citizenship In The French Colonies. Chicago: University of Chicago Press.

Scheele, J. (2010). 'Coming to Terms with Tradition. Manuscript Conservation in Contemporary Algeria'. In: The Trans-Saharan Book Trade. Manuscript Culture, Arabic Literacy and Intellectual History in Muslim Africa. Ed. by G. Krätli and G. Lydon. Leiden: Brill, pp. 291-318.

Sebaa, R. (1996). L'arabisation dans les sciences sociales: le cas algérien. Paris: L'Harmattan.

Shamsul, A. B. (2001). 'A History of an Identity, an Identity of a History. The Idea and Practice of 'Malayness' in Malaysia Reconsidered'. In: Journal of Southeast Asian Studies 32(3), 355-366.

Shaw, F. (8th Jan. 1897). 'Nigeria'. In: The Times.

Shepard, T. (2006). 'Pied-Noirs, Bêtes Noires. Anti-“European of Algeria” Racism and the Close of the French Empire'. In: Algeria \& France, 1800-2000. Identity, Memory, Nostalgia. Ed. by P. M. E. Lorcin. Syracuse: Syracuse University Press, pp. 150-163.

Silverstein, M. (2010). 'Society, polity, and language community: An enlightenment trinity in anthropological perspective'. In: Journal of Language and Politics 9(3), 339-363.

Spolsky, B. (2004). Language Policy. Cambridge: Cambridge University Press.

Suleiman, Y. (2013). 'Arabic Folk Linguistics. Between Mother Tongue and Native Language'. In: The Oxford Handbook of Arabic Linguistics. Ed. by J. Owens. Oxford: Oxford University Press, pp. 264-281.

Taleb Ibrahimi, A. (2008). Mémoires d'un Algérien. Tome 2: La passion de bâtir (1965-1978). Alger: Casbah.

Taleb Ibrahimi, K. (1995). Les Algériens et leur(s) langue(s): éléments pour une approche sociolinguistique de la société algérienne. Algiers: Editions el Hikma.

Temim, D. (2007). 'Nomination et représentation des langues en Algérie'. In: Les enjeux de la nomination des langues dans l'Algérie contemporaine. Ed. by F. Chériguen. Paris: L'Harmattan, pp. 19-35.

Temlali, Y. (2015). La genèse de la Kabylie: Aux origines de l'affirmation berbère en Algérie (1830-1962). Alger: Barzakh.

Turin, Y. (1971). Affrontements culturels dans l'Algérie coloniale. Ecoles, Médecines, et Religion, 1830-1880. Paris: François Maspero.

Vertovec, S. (2007). 'Super-diversity and its implications'. In: Ethnic and Racial Studies 30(6), 1024-1054.

- (2010). 'Towards post-multiculturalism? Changing communities, conditions and contexts of diversity'. In: International Social Science Journal 61(199), 83-95.

- (2016). Super-diversity. London: Routledge.

Wright, S. (2016). Language Policy and Language Planning. From Nationalism to Globalisation. 2nd ed. Basingstoke: Palgrave Macmillan.

Yildiz, Y. (2012). Beyond the Mother Tongue. The Postmonolingual Condition. New York: Fordham University Press. 
Zhou, M. and X. Wang (2017). 'Introduction. understanding language management and multilingualism in Malaysia'. In: International Journal of the Sociology of Language 2017(244), 1-16. 